\title{
Penerapan Metode Fuzzy Tsukamoto pada Sistem Pakar untuk Mendiagnosa Autisme Pada Anak
}

\author{
Neng Ika Kurniati ${ }^{1}$, R. Reza El Akbar ${ }^{2}$, Panji Wijaksonoc ${ }^{3}$ \\ ${ }^{1,2,3}$ Porogram Studi Informatika Universitas Siliwangi \\ Inengikakurniati@unsil.ac.id, ${ }^{2}$ reza@unsil.ac.id, ${ }^{3}$ panjiwijaksono@gmail.com
}

\section{INFORMASI ARTIKEL}

Sejarah Artikel:

Diterima Redaksi:

Revisi Akhir:

Diterbitkan Online:

\begin{tabular}{l} 
KATA KunCI \\
\hline Autisme \\
Logika Fuzzy \\
Sistem Pakar \\
Tsukamoto \\
KORESPONDENSI \\
\hline
\end{tabular}

Telepon: +62 85223518587

E-mail: nengikakurniati@unsil.ac.id

\section{PENDAHULUAN}

Autisme lebih tepat dikatakan sebuah sindrom, yang merupakan kumpulan gejala yang seringkali berbeda pada tiap individu dan tiap keadaan. Gejala dan perlakuan terhadap anak penderita autis berbeda. Anak autisme mengalami gangguan berkomunikasi, interaksi sosial, perilaku, emosi, serta proses sensoris [1].

Rumusan Masalah yang ada pada penelitain ini adalah kurangnya pengetahuan bagi orang tua untuk mendiagnosa dan penangan dini gangguan autisme pada anak, kurangnya unit layanan konsultasi bagi orang tua dan para orang tua sendiri enggan melakukan konsultasi ke ahli psikolog atau kejiwaan, serta mahalnya biaya untuk konsultasi Dibutuhkannya sebuah sistem yang dapat menampung pengetahuan ahli pakar autisme dan informasi - informasi seputar autisme sehingga orang tua bisa melakukan melakukan penanganan secara dini.

Batasan masalah yang ada pada penelitian ini adalah Sistem pakar ini hanya membahas gejala - gejala autisme yang dialami oleh anak yang memiliki gangguan ADHD
Gangguan yang terjadi pada perkembangan anak seperti gejala autisme dapat eteksi sejak dini. Jumlah anak pengidap autisme dalam setiap tahun semakin meningkat. Oleh karena itu, perlu adanya tindakan deteksi dini pada anak oleh orang tua agar mengetahui adanya kelainan pada anak dalam masa kembang sehingga dapat melakukan penanganan secara dini dan dapat menurunkan resiko terjadinya gangguan pada perkembangan anak dimasa yang memerlukan cara penalaran manusia dalam mendeteksi gejala tersebut. Metode pendekatan terhadap ketidakpastian yang menggambarkan taraf atau tingkat keanggotaan objek pada himpunan gejala yang timbul pada anak. Dalam hal ini perlu adanya sistem yang dapat mengakomodasi keilmuan seorang pakar terutama dalam mendiagnosa autisme sehingga dapat digunakan dengan mudah oleh para orang tua dalam mendeteksi gejala autisme pada anak. Tujuan dari penelitian ini yaitu membangun sistem pakar yang mampu melakukan diagnosis dihasilkan dari hasil penelitian ini adalah Memberikan pengetahuan tentang gejala awal autisme pada anak bagi para orang tua, diharapkan mampu membantu para orang tua untuk melakukan penangan awal bagi anak autisme, selain itu dapat digunakan oleh guru / psikiater yang menangani autisme untuk mempermudah dalam memeriksa pasien.
(Attention Deficit Hyperaktivity Disorder), Metode Fuzzy Tsukamoto digunakan untuk memperoleh rules dan mendiagnosis autisme pada anak, Hasil output dari aplikasi adalah tingkat autisme pada yang melakukan diagnosis, Aplikasi sistem pakar ini berupa aplikasi berbasi web menggunakan framework dan MySQL.

Tujuan dari penelitian ini adalah untuk merancang dan membangun suatu program aplikasi sistem pakar yang mampu memberikan diagnosis autisme pada anak yang memiliki gangguan ADHD, berdasarkan gejala - gejala yang dialami oleh seorang anak dalam komunikasi, interaksi sosial serta pola perilaku anak setiap hari dan hasil diagnosis tersebut akan lebih memudahkan orang tua untuk melakukan tindakan yang paling tepat untuk anak yang menderita autis.

Manfaat yang dapa dihasilkan dari hasil penelitian ini adalah Memberikan pengetahuan tentang gejala awal autisme pada anak bagi para orang tua, diharapkan mampu membantu para orang tua untuk melakukan penangan awal bagi anak autisme, selain itu dapat digunakan oleh guru / psikiater yang menangani autisme untuk mempermudah dalm memeriksa pasien. 


\section{LANDASAN TEORI}

\subsection{Autisme}

Autis adalah gangguan perkembangan pervasif pada anak yang ditandai dengan adanya gangguan dan keterlambatan dalam bidang kognitif, bahasa, perilaku, komunikasi, dan interaksi sosial. Autisme bisa terdeteksi pada anak berumur paling sedikit 1 tahun. Gejala autis infantil timbul sebelum anak mencapai usia 3 tahun. Terdapat beberapa gangguan yang terjadi pada anak auitis salah satunya gangguan dalam bidang interaksi sosial [6].

\subsection{Sistem Pakar}

Secara umum, sistem pakar (expert system) adalah system yang berusaha mengadopsi pengetahuan manusia ke komputer, agar komputer dapat menyelesaikan masalah seperti yang biasa dilakukan oeh para ahli.

Menurut Giarratano dan Riley : Sistem pakar adalah suatu sistem komputer yang bisa menyamai atau meniru kemampuan seorang pakar [2].

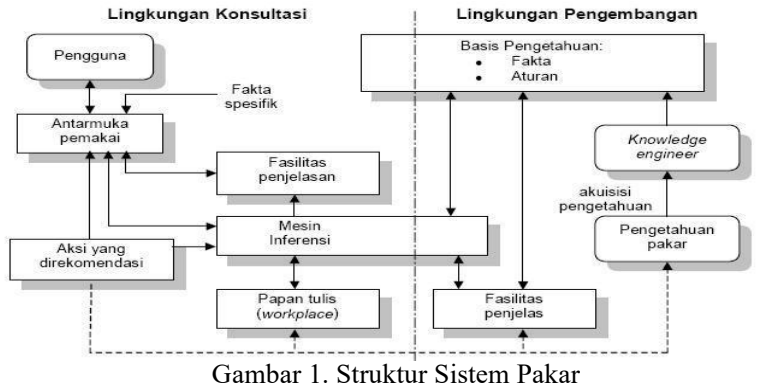

\subsection{Logika Fuzzy}

Fuzzy Logic berhubungan dengan ketidak pastian yang telah menjadi sifat alamiah manusia, mensimulasikan proses pertimbangan normal manusia dengan jalan kemnungkinan computer untuk berperilaku sedikit lebih seksama dan logis dari pada [2].

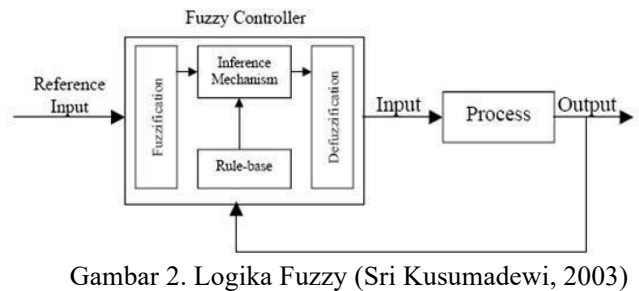

\subsection{Metode Fuzzy Tsukamoto}

Metode Fuzzy Tsukamoto, keterkaitan aturan berbentuk "Sebab dan Akibat" dan juga keterkaitan "Input dan Output" harus ada hubungannya antara aksi dan kondisi.

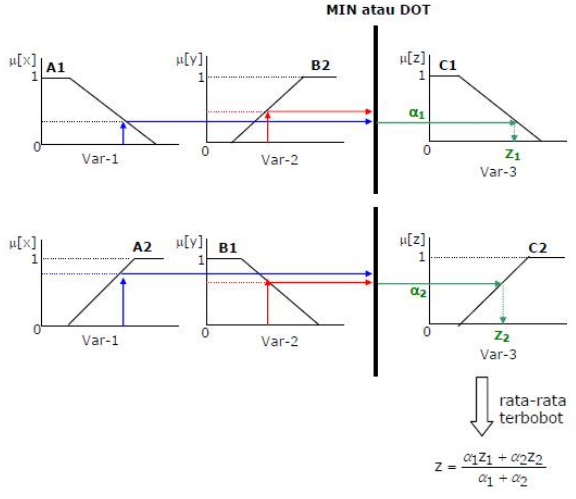

Gambar 3. Inferensi Fuzzy Tsukamoto

\section{METODOLOGI}

\subsection{Metodologi Pengembangan Sistem}

Dalam pengembangan sistem pakar ini, metodologi yang digunakan adalah Expert System Development Life Cyrcle (ESDLC) yang meliputi enam tahapan pokok.

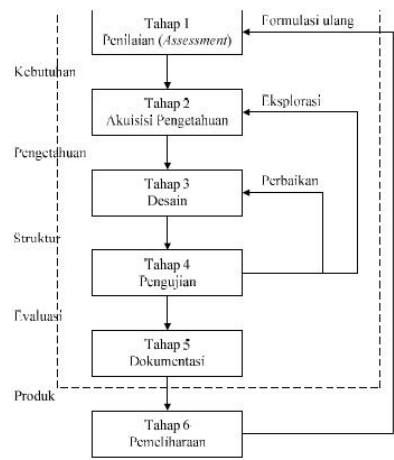

Gambar 4. Expert System Development Life Cycle ( Turban, 2005)

Alasan utama memilih metode pengembangan sistem ESDLC adalah metode pengembanfan sistem ESDLC khusus untuk perancangan aplikasi sistem pakar. [3].

a. Pembuatan Tabel Keputusan (Decision Table)

Tabel keputusan merupakan suatu metode untuk mendokumentasikan pengetahuan.

Tabel Keputusan (Decision Table)

\begin{tabular}{|c|c|c|c|c|}
\hline Rule & Inattentiveness & Hiperaktivitas & Impulsivitas & $\begin{array}{c}\text { Inattentiveness } \\
\text { AND } \\
\text { Hiperaktivitas } \\
\text { AND } \\
\text { Impulsivitas }\end{array}$ \\
\hline R1 & RENDAH & RENDAH & RENDAH & RENDAH \\
\hline R2 & RENDAH & RENDAH & TINGGI & RENDAH \\
\hline R3 & RENDAH & TINGGI & RENDAH & RENDAH \\
\hline R4 & RENDAH & TINGGI & TINGGI & TINGGI \\
\hline R5 & TINGGI & RENDAH & RENDAH & TINGGI \\
\hline R6 & TINGGI & RENDAH & TINGGI & TINGGI \\
\hline R7 & TINGGI & TINGGI & RENDAH & TINGGI \\
\hline R8 & TINGGI & TINGGI & TINGGI & TINGGI \\
\hline & & & &
\end{tabular}




\subsection{Design}

Perancangan Sistem Pakar Diagnosa Autis meliputi :

\section{Perancangan Flowchart}

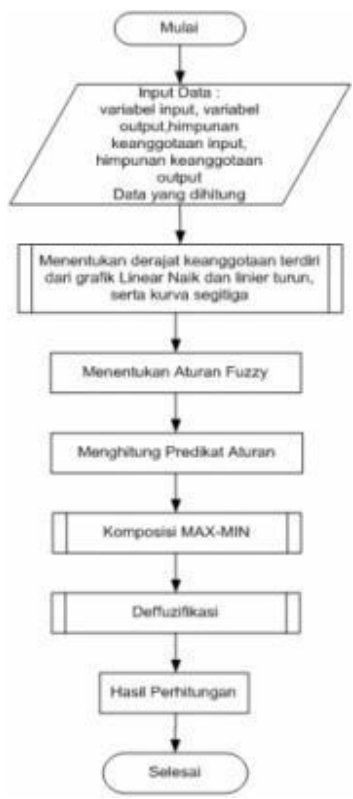

Gambar 5. Flowchart Logika Fuzzy

\section{a. Himpunan Fuzzy}

Bagian ini menentukan variabel - variabel yang akan digunakan sebagai data yang mempengaruhi dalam menganalisa autisme pada anak yaitu ada 3 variabel, tidak

mampu memusatkan perhatian (inattentiveness), hiperaktivitas, dan perilaku impulsive (Impulsiveness). Variabel - variabel tersebut diubah dahulu menjadi bentuk himpunan fuzzy.

b. Pembentukan Aturan

Pembentukan variabel dan himpunan fuzzy, dibentuk aturan yang sesuai dengan mengambil data - data yang terdapat pada Skala Penilaian Perilaku Anal Hiperaktif Indonesia (SPPAHI) Indonsesian ADHD Rating Scale (IARS).

c. Aplikasi Fungsi Implikasi

Aturan dibentuk, maka dilakukan aplikasi fungsi aplikasi dengan memberikan suatu kasus tertentu ke dalam aplikasi tersebut. Pada tahap ini akan didapatkan predikaat sebagai aturan untuk perhitungan berikutnya.

d. Komposisi Aturan

Mendapatkan aturan dalam bentuk himpunan berdasarkan predikat yang telah diperoleh. Pada tahap ini akan didapatkan keanggotaan sebagai jawaban (masih dalam bentuk bilangan fuzzy).

e. Defuuzy

Beberapa metode defuzzy pada komposisi aturan metode Tsukamoto. Dari proses tahap ini akan menghasilkan jawaban atas data - data dari kasus yang telah diberikan. [4].

\section{Perancangan Database}

Perancangan database menggunakan ERD, terdapat 6 (enam) entitas dapat dilihat pada gambar 6 .

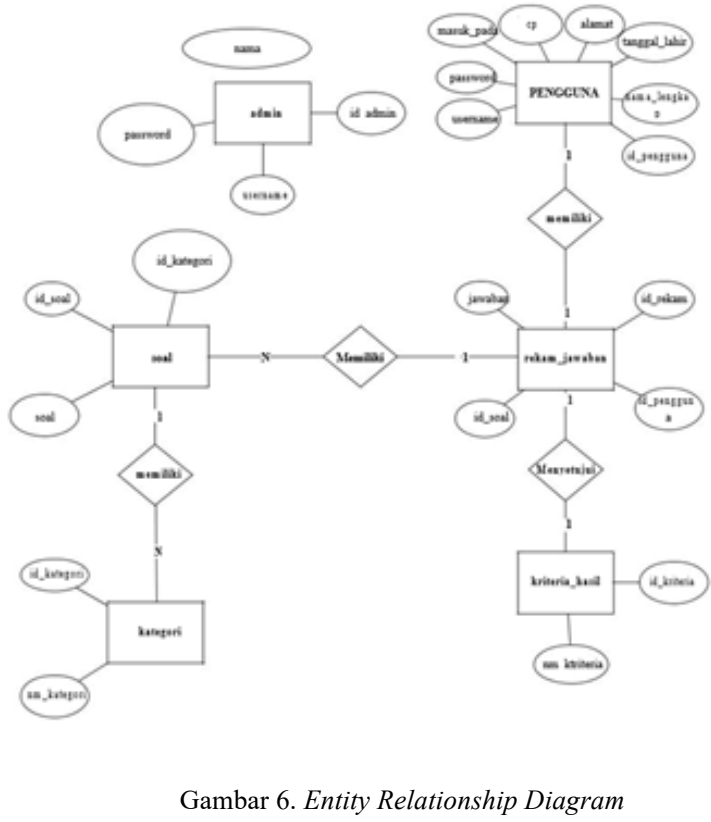

Ada 6 tabel dalam database fuzzy yang terdiri dari tabel admin, table pengguna, tabel kategori, tabel soal, table kriteria hasil, table rekam jawaban, dan tabel solusi. Yang terdiri dari primary key untuk tabel admin adalah id_admin, untuk tabel pengguna adalah id_pengguna, tabel kategori adalah id_kategori, tabel soal adalah id_soal, tabel kriteria_hasil adalah id_kriteria, tabel solusi adalah id_solusi, tabel rekam_jawaban adalah id rekam, dan tabel admin adalah id admin.

\section{Perancangan DFD}

\section{a. Contex Diagram}

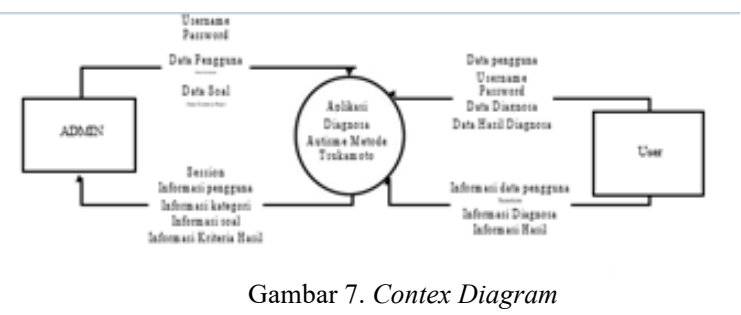

Context Diagram menjelaskan alur proses dari keseluhuran pada Aplikasi Diagnosa Autisme Metode Tsukamoto. Ada 2 pengguna pada aplikasi ini yaitu Admin dan User . Admin mempunyai hak akses untuk mengatur isi dari aplikasi dan user sebagai pengguna aplikasi yang hanya bisa menggunakan aplikasi untuk mendiagnosa saja. 


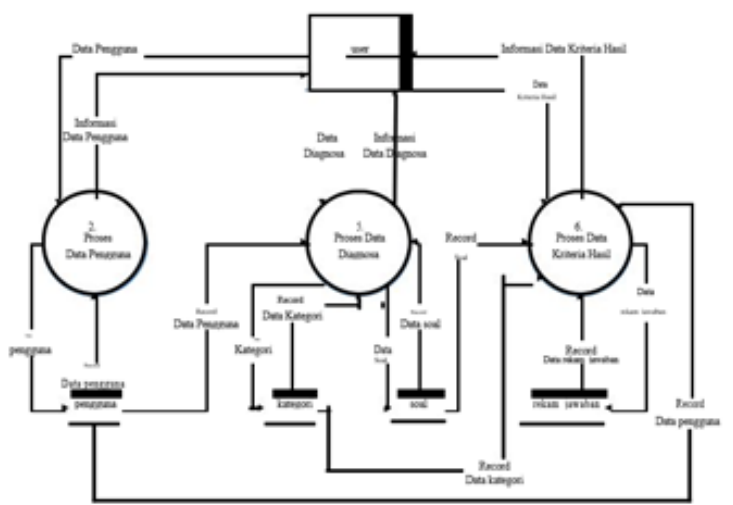

Gambar 8. DFD Level 2 Diagnosa

\section{b. DFD Level 2 Data Diagnosa}

Proses DFD level 2 data diagnosa terdapat 3 tahapan proses yang pertama user memproses data pengguna, setelah beres pada proses data pengguna kemudian user bisa masuk pada proses data diagnose yang berisikin data dari tabel kategori, dan tabel soal yang memiliki data dari setiap pernyataan yang harus diisi oleh user. Proses terakhir masuk pada proses data kriteria hasil yang memberikan informasi hasil dari kedua proses tersebut yang memiliki data dari tiap tabel dan disimpan dalam tabel rekam_jawaban.

\section{HASIL DAN PEMBAHASAN}

\section{A. Implementasi Sistem}

Tahapan ini merupakan tahapan dimana hasil dari perancangan antarmuka yang telah diimplementasikan kedalam program yang dibuat dengan menggunakan bahasa pemrograman PHP dengan menggunakan Framework dan basis data yang digunakan adalah MySQ1.

\section{Form Beranda}

Form Beranda ini merupakan tampilan awal dari aplikasi , pada tahap ini terdapat pilihan untuk mengakses menu „Mulai Diagnosa", "Beranda"e, "Penjelasan", „Hasil Diagnosa ${ }^{e e}$, dan ,Logout

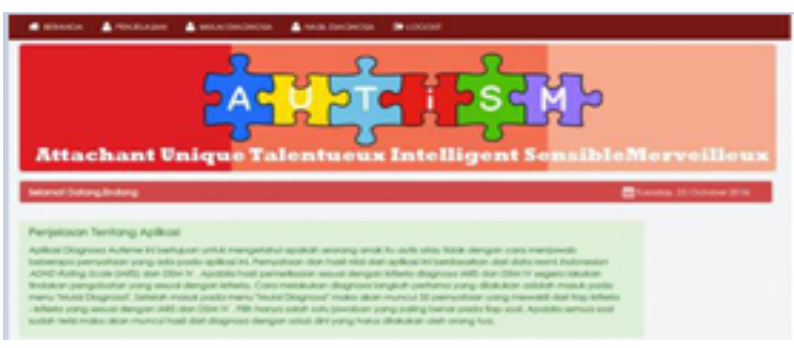

Gambar 9. Beranda

\section{Form Diagnosa}

Pada from ini pengguna menjawab semua pernyataan yang berjumlah 35 pernyataan yang terbagi dalam 3 kategori, yaitu kategori tidak mampu memusatkan perhatian, hiperaktivitas, dan impulsifitas.

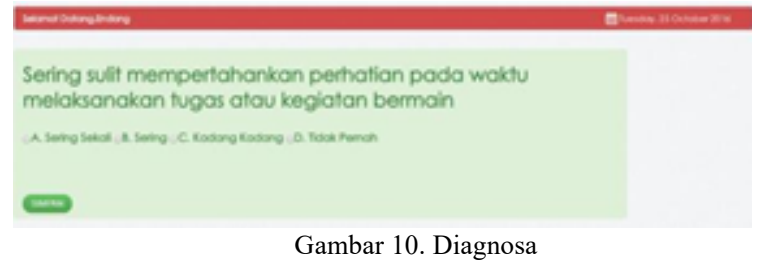

\section{B. Pengujian Akurasi Manual}

Analisis Perhitungan Metode menjelaskan perhitungan tingkat autis menggunakan Fuzzy Tsukamoto. Sebelumnya telah dilakukan penyebaran kuisioner instrument IARS kepada 15 murid Sekolah Dasar SLB di Ciamis sebagai objek penelitian.

Dari data - data tersebut diambil satu objek penelitian sebagai kasus pada analisis perhitungan metode Fuzzy Tsukamoto. Misalkan kasus yang diambil adalah data milik Nabil Muhamad Zaky dengan skor Faktor Inattentiveness: 8, skor Faktor Hiperaktif : 5 dan skor Faktor Impulsivitas : 3. Representasi Linier Naik Inattentiveness

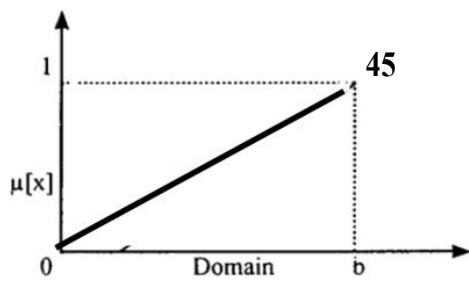

Fungsi Keanggotaan :

$\mu[8]= \begin{cases}0 ; & 8 \leq 0 \\ (8-0) /(45-0) ; & 0 \leq 8 \leq 45 \\ 1 ; & 8 \geq \mathrm{b}\end{cases}$

Nilai Keanggotan Inattentiveness Linear Naik :

$\mu$ FINtinggi $=(8-0) /(45-0)$

$=0.177$

Representasi Linier Turun Inattentiveness

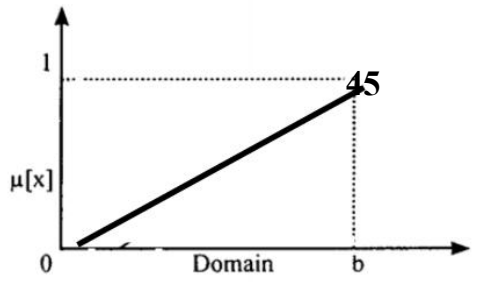

Fungsi Keanggotaan :

$\mu[8]= \begin{cases}1 ; & 8 \leq 0 \\ (45-8) /(45-0) ; & 0 \leq 8 \leq 45 \\ 0 ; & 8 \geq \mathrm{b}\end{cases}$

Nilai Keanggotan Inattentiveness Linear Turun :

$\mu$ FINrendah $=(45-8) /(45-0)$

$=0.822$ 
Representasi Linier Naik Hiperaktivitass

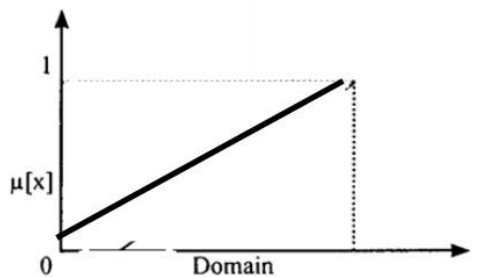

Fungsi Keanggotaan :

$\mu[5]= \begin{cases}0 ; & 5 \leq 0 \\ (5-0) /(27-0) ; & 0 \leq 5 \leq 27 \\ 1 ; & 5 \geq b\end{cases}$

Nilai Keanggotan Hiperaktivitas Linear Naik :

$$
\begin{aligned}
\mu \text { FHtinggi } & =(5-0) /(27-0) \\
& =0.185
\end{aligned}
$$

Representasi Linier Turun Hiperaktivitas

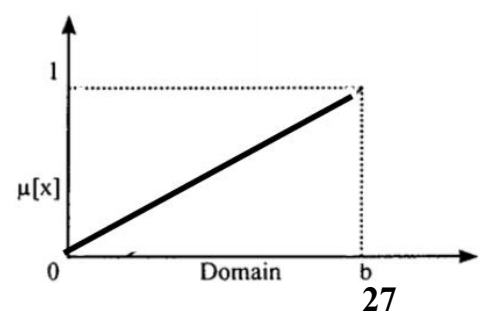

Fungsi Keanggotaan :

$\mu[5]= \begin{cases}1 ; & 5 \leq 0 \\ (27-5) /(27-0) ; & 0 \leq 5 \leq 27 \\ 0 ; & 5 \geq b\end{cases}$

Nilai Keanggotan Hiperkativitas Linear Turun :

$\mu$ FHrendah $=(27-5) /(27-0)$

$$
=0.814
$$

Representasi Linier Naik Impulsivitass

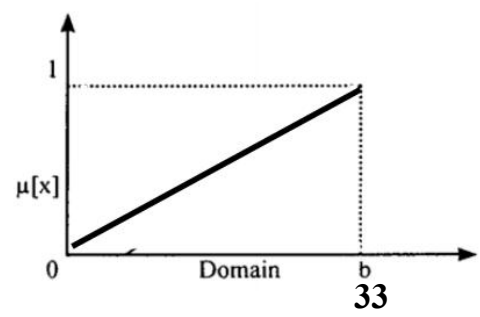

Fungsi Keanggotaan :

$\mu[3]= \begin{cases}0 ; & 3 \leq 0 \\ (3-0) /(33-0) ; & 0 \leq 3 \leq 33 \\ 1 ; & 5 \geq b \text { Nilai Keanggotan }\end{cases}$

Impulsivitas Linear Naik :

$\begin{aligned} \mu \text { FIPtinggi } & =(3-0) /(33-0) \\ & =0.09\end{aligned}$
Representasi Linier Turun Impulsivitas

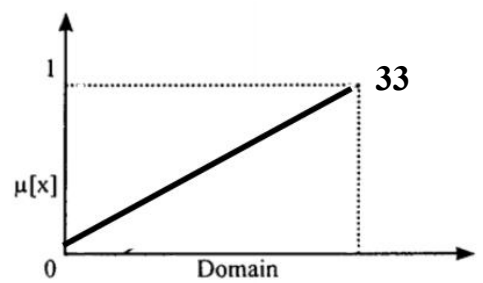

Fungsi Keanggotaan :

$\mu[3]= \begin{cases}1 ; & 3 \leq 0 \\ (33-3) /(33-0) ; & 0 \leq 3 \leq 33 \\ 0 ; & 3 \geq b\end{cases}$

Nilai Keanggotan Impulsivitas Linear Turun :

$\mu$ FIPrendah $=(33-3) /(33-0)$

$$
=0.90
$$

Nilai $\alpha_{-}$pred $_{1}=\mathrm{MIN}(\mu \mathrm{FINrendah,}$ $\mu$ FHrendah, $\mu$ FIPrendah, $)=0.822$

Nilai $Z_{1} \quad=\left(105^{*} \alpha_{-}\right.$pred $\left._{1}\right)-105=19.95$

Nilai $Z$ dapat dicari dengan :

\begin{tabular}{|c|c|}
\hline Node & Source Code \\
\hline 1. & \$nilaia1 = "0"; \\
\hline 2. & \$nilaib1 = "45"; \\
\hline 3. & If \$nilaiIN $<=$ a Then \\
\hline 4. & $\$ F I N m a x=0$ \\
\hline 5. & ElseIf $\mathrm{a}<=$ \$nilaiIN $<=\mathrm{b}$ Then \\
\hline & $\$$ FINmin $=($ \$nilaiIN - \$nilaia1 $/$ \\
\hline & (\$nilaib1 - \$nilaia1) \\
\hline 7. & ElseIf SnilaiIN $>=b$ Then \\
\hline 8. & $\$$ FINmax $=1$ \\
\hline 9. & End If \\
\hline
\end{tabular}

$$
\begin{aligned}
& Z=\left(Z_{1} * \alpha_{-} \text {pred }_{1}\right)+\left(Z_{2} * \alpha_{-} \text {pred }_{2}\right)+\left(Z_{3} * \alpha_{-} \text {pred }_{3}\right. \\
& )+\left(Z_{4} * \alpha_{-} \text {pred }_{4}\right)+\left(Z_{5} * \alpha_{-} \text {pred }_{5}\right)+\left(Z_{6} *\right. \\
& \left.\alpha_{-} \operatorname{pred}_{6}\right)+\left(Z_{7} * \alpha_{-} \text {pred }_{7}\right)+\left(Z_{8} * \alpha_{-} \text {pred }_{8}\right) \\
& \text { / }\left(\alpha_{-} \text {pred }_{1}+\alpha_{-} \text {pred }_{2}+\alpha_{-} \text {pred }_{3}+\alpha_{-} \text {pred }_{4}+\right. \\
& \left.\alpha_{-} \text {pred }_{5}+\alpha_{-} \text {pred }_{6}+\alpha_{-} \text {pred }_{7}+\alpha_{-} \text {pred }_{8}\right) \\
& =(0.822 * 19.95)+(0.09 * 9.45)+(0.19 * 19.95)+ \\
& (0.09 * 9.45)+ \\
& \begin{array}{l}
(0.18 * 18.9)+ \\
(0.09 * 9.45) /
\end{array}(0.09 * 9.45)+(0.18 * 18.9) \\
& (0.822+0.09+0.19+0.09+0.18+0.09+0.18+0.09) \\
& =\mathbf{1 7 . 5 5}
\end{aligned}
$$

\section{Pengujian Whitebox}

a. Himpunan Keanggotaan

Tabel 3.21 Himpunan Keanggotaan 
Flow Graph Himpunan Keanggotaan Algoritma Fuzzy Logic berdasarkan pseudocode di atas maka flow graph algoritma fuzzy logic adalah sebagai berikut:

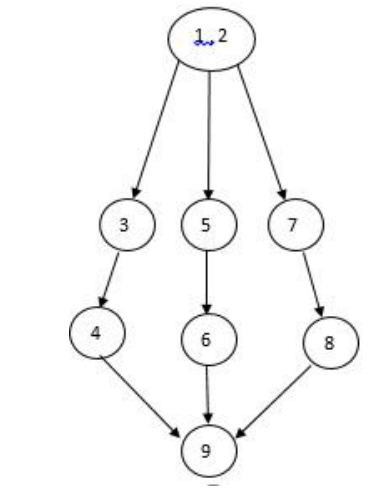

Gambar 11. Cyclomatic Complexity

Himpunan Keanggotaan

Dari gambar diatas dapat ditentukan Cyclomatic

Complexity sebagai berikut :

$$
\begin{aligned}
\mathrm{V}(\mathrm{G}) & =\mathrm{E}-\mathrm{N}+2 \\
& =9-8+2 \\
& =3
\end{aligned}
$$

\section{E. Pengujian Akurasi IARS}

Sistem penilaian pada aplikasi Sistem Pakar Menggunakan Metode Fuzzy Tsukamoto untuk Diagnosa Autisme Pada Anak ini berdasarkan uji coba pada objek penelitian sebanyak 15 responden. Dari hasil uji coba

\begin{tabular}{|c|c|c|c|c|c|}
\hline \multirow{2}{*}{ No. } & \multirow{2}{*}{ Nama Lengkap } & \multicolumn{2}{|c|}{ Total Skor } & \multicolumn{2}{|c|}{ Tingkat Autis } \\
\hline & & IARS & Tsukamoto & IARS & Tsukamoto \\
\hline 1. & Bill Jihad Kurnia & 45 & 45,31 & Tinggi & Tinggi \\
\hline 2. & Rizki Anugrah & 37 & 38,72 & Tinggi & Tinggi \\
\hline 3. & $\begin{array}{l}\text { Johanses Julius } \\
\text { Agung }\end{array}$ & 55 & 40 & Tinggi & Tinggi \\
\hline 4. & $\begin{array}{l}\text { Fauzzy Abdul } \\
\text { Hamid }\end{array}$ & 40 & 38,77 & Tinggi & Tinggi \\
\hline 5. & $\begin{array}{l}\text { Denziana Queen } \\
\text { Azzura }\end{array}$ & 80 & 53,77 & Tinggi & Tinggi \\
\hline 6. & $\begin{array}{l}\text { Arie Supritana } \\
\text { Pamungkas }\end{array}$ & 25 & 28.85 & Rendah & Rendah \\
\hline 7. & Rejasida & 50 & 45.55 & Tinggi & Tinggi \\
\hline 8. & Teguh & 40 & 38,29 & Tinggi & Tinggi \\
\hline 9. & Annisa & 39 & 32,55 & Tinggi & Tinggi \\
\hline 10. & Rafka & 55 & 50,89 & Tinggi & Tinggi \\
\hline 11. & $\begin{array}{l}\text { M Fauzi } \\
\text { Taufiqurahman }\end{array}$ & 26 & 25,68 & Rendah & Rendah \\
\hline 12. & $\begin{array}{l}\text { Nabil Muhammad } \\
\text { Zaky }\end{array}$ & 16 & 17,19 & Rendah & Rendah \\
\hline 13. & Mahar Budiman & 32 & 28,54 & Tinggi & Tinggi \\
\hline 14. & $\begin{array}{l}\text { Ardiana Az - Zahra } \\
\text { Putri }\end{array}$ & 23 & 22,94 & Rendah & Rendah \\
\hline 15. & Dannis & 24 & 21,26 & Rendah & Rendah \\
\hline
\end{tabular}
diperoleh kesesuaian antara tingkat autis IARS dan Fuzzy Tsukamoto sebanyak 15 data.

Dengan probabilitas kesesuaian tingkat autis antara perhitungan

IARS dengan perhitungan Fuzzy Tsukamoto adalah :

$$
\begin{aligned}
& \text { Psesuai }=\longrightarrow \times 100 \% \\
& =-\mathrm{X} 100 \% \\
& =100 \%
\end{aligned}
$$

Dan probabilitas ketidak sesuaian tingkat autis antara perhitungan IARS dengan perhitungan Fuzzy Tsukamoto adalah :

Ptidaksesuai

$$
\begin{aligned}
& =-\times 100 \% \\
& =-\times 100 \% \\
& =0 \%
\end{aligned}
$$

Melihat nilai probabilitas yang mencapai kesesuaian data mencapai $100 \%$, menunjukkan bahwa sistem pakar ini sudah berfungsi dengan baik. Dengan demikian, diharapkan sistem pakar ini dapat membantu dalam perhitungan dalam mencari nilai tingkat autisme pada anak.

\section{KESIMPULAN}

Setelah melakukan serangkaian penelitian, maka pada bab ini akan menyimpulkan dari uraian penelitian pada bab sebelumnya. Kesimpulan yang diperoleh adalah sebagai berikut :

1. Penalaran Metode fuzzy tsukamoto dapat melakukan diagnosa autisme berdasarkan gejala-gejala yang dialami oleh anak-anak penyandang autisme ADHD dengan memiliki nilai ketidakpastian dengan aturan IARS yang direpresentasikan dari pakar.

2. Diagnosa Autisme ADHD (Attention Deficit Hyperaktivity Disorder) dapat dilakukan dengan menggunakan logika fuzzy tsukamoto dengan persentasi keakuratan dengan hasil perhitungan IARS sebesar $100 \%$.

Berdasarkan kesimpulan yang telah dikemukakan, dapat diajukan beberapa saran untuk pengembangan lebih lanjut, diantaranya :

1. Perlu adanya perubahan fungsi keanggotaan yang digunakan serta melakukan penambahan rule dan juga rentang parameter yang digunakan sehingga tingkat kesalahan yang dihasilkan oleh perhitungan fuzzy dapat diperkecil..

2. Saran untuk pengembangkan aplikasi deteksi dini autisme adalah dengan membuat aplikasi berbasis mobile dan pengembangan metode lain seperti Jaringan saraf tiruan untuk proses identifikasi.

\section{DAFTAR PUSTAKA}

[1] Imaculata, U, "Bina Diri dan Perilaku", Jakarta :MAS Publishing, 2011.

[2] Kusumadewi,S, Artificial Intelligence (Teknik dan Aplikasinya). Yogyakarta. Graha Ilmu.2003.

[3] Durkin, J, "Expert Systems Design and Developmen". New Jersey: Prentice Hall International Inc. 1994

[4] Ayuningtyas, I. K., Saptono, F., \& Hidayat, T. (2007). Sistem Pendukung Keputusan Penanganan Balita Menggunakan Penalaran Fuzzy Mamdani. Seminar Nasional Aplikasi Teknologi Informasi 2007 (SNATI 2007), L65-L71. Khusus, Bandung : Graha Ilmu. 
[6] Huzaemah, 2010. Kenali Autisme sejak dini, yayasan pustaka obor, Jakarta.

[7] Suriansyah, M. I., \& Novianti, S. (2012). Pendahuluan Metodologi Penelitian, 329-334.

[8] Kusumadewi, Sri dan Hartati, Sri. 2006. Neuro Fuzzy-Integrasi Sistem Fuzzy dan Jaringan Syaraf. Yogyakarta: Graha

[9] Raising children network, 2013, Myths about ASD. http://www.raisingchildren.net.au.

\section{BIODATA PENULIS}

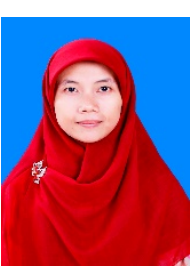

Neng Ika Kurniati

Tempat tanggal lahir di Ciamis 25 Juli 1982, merupakan Dosen Teknik Informatika, Universitas Siliwangi. Menyelesaikan S1 di Universitas Padjadjaran dan S2 di Universitas Gadjah

Mada

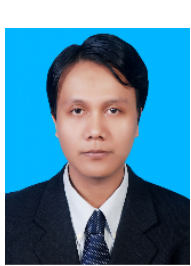

R. Reza El Akbar

Tempat tanggal lahir di Tasikmalaya 26 Juli 1983, merupakan dosen Teknik Informatika, Universitas Siliwangi. Menyelesaikan S1 di Universitas Padjadjaran dan S2 di Institut Teknologi Bandung dan STMIK LIKMI Bandung.

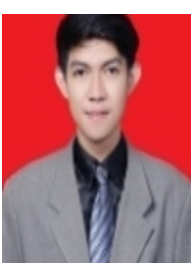

Panji Wijaksono

merupakan alumni Teknik Informatika, Fakultas Teknik, Universitas Siliwangi. Menyelesaikan S1 di Universitas Siliwangi 